STUDIA POLONIJNE

T. 42 LUBLIN 2021

DOI: $\overline{\text { http://doi.org/10.18290/sp2142.20 }}$

JACEK GOŁĘBIOWSKI

\title{
SZKOLNICTWO POLSKIE W STANACH ZJEDNOCZONYCH
}

Zorganizowanie polskiego szkolnictwa na wychodźstwie w Ameryce w ostatnich dekadach XIX wieku i pierwszych wieku XX należy do najcenniejszych inicjatyw podejmowanych przez polskich emigrantów. Podjęcie tego zadania, jednego z najważniejszych tuż po założeniu parafii i wybudowaniu świątyni, w sposób szczególny spajało polską społeczność. Parafia, nierozerwalnie połączona ze szkołą, stanowiła centrum polskości, w którym pielęgnowano nasz język, kulturę, tradycje i obyczaje, jako antidotum na wynarodowienie i obojętność religijną ${ }^{1}$.

Ksiądz Wacław Kruszka, autor Historyi polskiej w Ameryce, w drugim tomie swojego dzieła, omawiając dzieje szkolnictwa polskiego w Ameryce, podkreślił, iż:

Bez szkoły polskiej kościół polski, jeśli pozostanie jeszcze katolickim, niechybnie stanie się irlandzkim, angielskim czy amerykańskim. Owe kościoły polskie, w których Polacy słyszą słowo Boże w swoim ojczystym języku - to twierdze patriotyzmu, to arki i korabie, które chronią lud polski na tutejszej obczyźnie od potopu i powodzi, wynarodowienia i cudzoziemszczyzny. Ale fundamentami tych twierdz są szkoły polskie! Bez nich Kościół polski zatonąłby w morzu anglo-amerykanizmu. Szkoły polskie, to najlepsze źródła i rozsadniki polskości i patriotyzmu na obcej amerykańskiej ziemi. Tam w tych szkołach parafialnych polskie dzieci nie tylko uczą się tego co w szkołach publicznych, czyli czytać, pisać i rachować, ale uczą się tam wiary w Boga i miłości do naszej Ojczyzny - Polski².

Dr hab. JACEK GOŁĘBIOwSKI, prof. KUL - Katedra Świata Hiszpańskiego, Polityki i Relacji Międzynarodowych w Instytucie Historii na Wydziale Nauk Humanistycznych Katolickiego Uniwersytetu Lubelskiego Jana Pawła II, Al. Racławickie 14, 20-950; e-mail: jacekgolebiowski@ kul.pl; ORCID: https://orcid.org/0000-0003-3082-2278.

${ }^{1}$ M.L. MisteCKa CR, Zmartwychwstanki. Charyzmat i dzieje, 1891-1991, t. II: Dziedzictwo (Biblioteka Polonii, t. 22), Lublin 1999, s. 369.

${ }^{2}$ W. KruszKa, Historya polska w Ameryce, t. II, Milwaukee 1905, s. 84. 
Pierwsze polskie szkoły parafialne w Ameryce powstały z inicjatywy naszego duchowieństwa i działały pod jego nadzorem i kierownictwem. W początkowej fazie rozwoju polskich osad istniały w nich małe szkółki niedysponujące własnym budynkiem i fachową kadrą nauczycielską. Funkcję szkoły pełniły izby mieszkalne, w których najbardziej kompetentni mieszkańcy uczyli dzieci podstaw języka polskiego i rachowania, a także elementarnych prawd wiary katolickiej, koniecznych przy przyjęciu sakramentów ${ }^{3}$. Pierwsze informacje o nauczaniu polskich dzieci przy parafii pochodzą z osady Panna Maria w Teksasie, założonej w 1854 r. Kolejne pojawiają się z miejscowości Polonia i Stevents Point w Wisconsin (1864), parafii św. Stanisława w Milwaukee (1868), parafii św. Stanisława Kostki w Chicago (1867), parafii św. Wojciecha w Detroit (1871) i parafii św. Stanisława w Buffalo $(1873)^{4}$. Z czasem wzrost liczby mieszkańców, podniesienie poziomu życia i świadomości obywatelskiej oraz narzucony w poszczególnych stanach wymóg obowiązku szkolnego sprawiły, że Polacy zaczęli angażować się w organizowanie profesjonalnych szkół przy parafiach. Uświadomiono sobie, że ich brak spowoduje konieczność wysyłania dzieci do państwowych szkół amerykańskich, w których będą pozbawione możliwości uczenia się języka polskiego i poznawania naszej historii, a także znacznie utrudni wychowanie ich w wierze katolickiej. Zdano sobie sprawę, iż dla młodego pokolenia jest to niebezpieczne, gdyż grozi utratą tożsamości. Od 1884 r. rozwój polskich szkół parafialnych został wzmocniony uchwałą plenarnego synodu biskupów amerykańskich w Baltimore, nakazującą proboszczom zakładanie szkół przy parafiach.

W polskich szkołach parafialnych zawsze dbano o zachowanie tradycyjnych wartości opartych na kulturze chrześcijańskiej, jednocześnie starając się włączyć w proces kształcenia najważniejsze elementy kultury amerykańskiej, wzmacniając w ten sposób rozwój odpowiedzialnego obywatela ${ }^{5}$.

Parafie wraz ze szkołami tworzyły jeden zintegrowany podmiot społeczny. Szkoła odgrywała ogromną rolę w umacnianiu więzi rodzinnych, ucząc szacunku dla autorytetów, a jednocześnie pomagając polskim imigrantom i ich dzieciom w dostosowaniu się do wymogów życia w społeczeństwie amerykańskim. Świadomych i odpowiedzialnych obywateli kształtowano poprzez edukację, która nie stroniąc od wyzwań współczesności, bazowała na

\footnotetext{
${ }^{3}$ Ks. A. ICIEK, Polacy w Ameryce, Poznań 1921, s. 13.

${ }^{4}$ Encyklopedia polskiej emigracji i Polonii, red. K. Dopierała, t. IV, Torun 2005, s. 460.

${ }^{5}$ M.J. Ziolkowski, The Felician Sisters of Livonia, Michigan: First Province in America, Detroit 1984, s. 69.
} 
tradycyjnych wartościach zaczerpniętych ze skarbnicy Kościoła katolickiego. Tak wyznaczone ramy nauczania i wychowania stały się filarami polsko-amerykańskiej wspólnoty dla kolejnych pokoleń ${ }^{6}$.

Największe zasługi na polu organizacji oświaty polskiej w Stanach Zjednoczonych przypisuje się ks. Józefowi Dąbrowskiemu, założycielowi i wieloletniemu rektorowi Seminarium Polskiego im. Świętych Cyryla i Metodego w Orchard Lake (Michigan), który wystarał się o sprowadzenie z Krakowa do Ameryki sióstr felicjanek. Zgromadzenie do pracy w polskich szkołach skierowało kilka tysięcy sióstr nauczycielek, które przez kilkadziesiąt lat swojej pracy wykształciły i wychowały kilkaset tysięcy dzieci polskich wychodźców.

Parafia przez cały czas trwania polskich wspólnot etnicznych w Ameryce była jedynym filarem oświaty polskiej. Organizując szkołę decydowała się na udźwignięcie ciężaru jej utrzymania. Zapewnienie finansów potrzebnych na jej bieżącą działalność, a także na przyszłe inwestycje spoczywały na parafianach. Kształcenie młodzieży najczęściej powierzano siostrom nauczycielkom z różnych zgromadzeń, ufając, że zadbają nie tylko o wysoki poziom nauczania, ale także przybliżą uczniom podstawy wiary i kultury polskiej, co scementuje wspólnotę parafialną na wiele pokoleń.

Duszpasterze polscy w Stanach Zjednoczonych przez całe dziesięciolecia utrzymywali się w przekonaniu, iż troska o szkołę parafialną jest bezdyskusyjnym priorytetem $\mathrm{w}$ ich pracy duszpasterskiej. Potwierdzenie tego zaangażowania znajdziemy w licznych wypowiedziach proboszczów utrwalonych w prasie parafialnej, kronikach i okolicznościowych wydawnictwach. W biuletynie „Bells of St. Mary” wydawanym w parafii pw. Matki Bożej Anielskiej w Chicago czytamy: „Szkoła parafialna jest ostoją ducha polskiego i katolickiego w Ameryce. Ze względu na obowiązek wychowania swoich dzieci w duchu prawdziwie religijnym i narodowym, rodzice powinni swoje dzieci posyłać do szkoły parafialnej. Materialnie żadna szkoła się nie opłaca. Jest ona wielkim ciężarem dla parafii, ale ciężar ten parafia chętnie ponosi, by podtrzymać ducha polskiego i katolickiego w młodym pokoleniu"7.

W księdze jubileuszu 25-lecia parafii pw. św. Michała Archanioła w Chicago (założonej w 1892 r.) czytamy:

Koroną naszego szczęścia, tu w Ameryce, jest bez wątpienia szkoła polska katolicka. Kto ma szkolnictwo w ręku, ten ma i przyszłość. Dlatego też nie tylko

\footnotetext{
${ }^{6}$ Tamże, s. 70.

${ }^{7}$ Szkoła parafialna, „Bells of St. Mary” 1945, nr 1, s. 2.
} 
Polacy, ale i katolicy innych narodowości pozakładali szkoły parafialne, licznie pokrywające kraj, w którym mieszkamy. Nie szczędzimy, my katolicy, ofiar pieniężnych, tym dotkliwszych, iż płacimy podwójny podatek szkolny: przymusowy na rzecz szkół publicznych i dobrowolny na rzecz szkół parafialnych. Jednakże nie w szkole publicznej leży nasza przyszłość polska w Ameryce, ale we własnej parafialnej, gdzie równocześnie z nauką świecką dziecko otrzymuje wychowanie religijne i moralne. Z Bogiem w sercu, dziecko polskie opuszcza szkołę na chwałę Bożą, na dobro własne i społeczeństwa polskiego. I znowu odsłania się doniosła korzyść naszych szkół parafialnych: wychowanie dziatwy w duchu czysto polskim. W języku polskim uczy się przeszłości narodowej swoich Ojców i dzieł wielkich pisarzy polskich. Szkoła parafialna zarazem religijna i polska, to błogosławieństwo dla teraźniejszości i pewny zadatek dla świetlanej przyszłości Polaków w Ameryce ${ }^{8}$.

Autor powyższego tekstu zwrócił uwagę na ważny fakt tworzenia szkolnictwa parafialnego przez większość katolickich grup etnicznych mieszkających w aglomeracji Chicago. Według danych statystycznych archidiecezji chicagowskiej, w 1924 r. na terenie miasta Chicago działały 232 parafie etniczne z łączną liczbą dzieci w szkołach parafialnych wynoszącą 127580 uczniów. Najwięcej z nich prowadzili Irlandczycy - 108, z liczbą uczniów 54067. Polskich parafii było wówczas 36, z łączną liczbą uczniów 43 336. Na trzecim miejscu uplasowały się parafie niemieckie - 32 z liczbą 14935 uczniów. Na kolejnych: włoskie - 12 parafii z 3167 uczniami, litewskie - 9 parafii z 4038 uczniami, słowackie - 9 parafii z 2678 uczniami, czeskie - 9 parafii z 2637 uczniami, francuskie - 5 parafii z 1405 uczniami, chorwackie 4 parafie z 767 uczniami. Pozostałe to parafie belgijskie, węgierskie, meksykańskie, holenderskie, syryjskie i afroamerykańskie. Analiza przytoczonych danych pokazuje, iż społeczność polska w Chicago była najbardziej zaangażowana $\mathrm{w}$ organizację i prowadzenie etnicznych szkół parafialnych. Średnio na jedną parafię polską przypadało 1204 uczniów, podczas gdy na irlandzką 500, a niemiecką 467. W przypadku innych narodowości liczba uczniów w parafii była jeszcze niższa (włoska - 264, litewska - 449, francuska - 281).

Analogiczna sytuacja miała miejsce w miastach leżących wokół Chicago. Irlandczycy prowadzili tam 58 parafii z liczbą uczniów 6364, Polacy - 16 parafii z 5909 uczniami, Niemcy - 27 parafii z 4960 uczniami, Francuzi - 7 parafii z 1272 uczniami, Słowacy - 3 parafie z 1867 uczniami, Włosi - 6 parafii z 722 uczniami, Czesi - 2 parafie z 572 uczniami, Chorwaci - jedną parafię z 304 uczniami $^{9}$.

\footnotetext{
${ }^{8}$ Pamiętnik 25-lecia Parafii Świętego Michała Archanioła w Chicago, Chicago 1917.

9 „Przegląd Kościelny” 1924, vol. 11, s. 356.
} 
W artykule zamieszczonym w jubileuszowym wydawnictwie $\mathrm{z}$ okazji 50-lecia parafii św. Jozafata w Chicago, dotyczącym walorów katolickiej edukacji, czytamy:

Zważywszy na proces kształtowania woli, rozwój charakteru i formacji religijnej, będących sprawami zasadniczymi dla katolickich rodziców - szkoły katolickie górują w tych działaniach nad publicznymi. Szkoły publiczne są w stanie nauczać i przekazywać wiedzę z nauk ścisłych i innych, ale brakuje im podstaw doktryny katolickiej kształtującej człowieka. W szkole katolickiej uczeń zyskuje korzyści nie tylko intelektualne, ale także moralne. Nauczanie jest utrwalane w umysłach i sercach, a poprzez dawanie odpowiedzi na odwieczne pytania: Skąd pochodzę? Kim jestem? Dokąd zmierzam? wypełnia swoją podstawową funkcję pełnego przygotowania do życia ${ }^{10}$.

Organizacje polonijne, działające na terenie Stanów Zjednoczonych, starały się wspierać szkolnictwo polskie między innymi poprzez organizowanie wydarzeń o charakterze patriotycznym i konkursy. Za przykład może tu posłużyć konkurs ortograficzny z języka polskiego organizowany od $1939 \mathrm{r}$. w Chicago przez Wydział Młodzieżowego Zjednoczenia Polskiego Rzymsko-Katolickiego. Jego wielokrotnymi laureatami byli uczniowie ze szkół prowadzonych przez siostry felicjanki ${ }^{11}$.

\section{1. ŻEŃSKIE ZGROMADZENIA ZAKONNE W STANACH ZJEDNOCZONYCH I ICH AKTYWNOŚĆ W SYSTEMIE POLSKICH SZKÓ£ PARAFIALNYCH}

Według danych statystycznych dotyczących polskiego szkolnictwa parafialnego w Stanach Zjednoczonych, zebranych i opublikowanych przez ks. Franciszka Bolka w pracy The Polish American school system, w 1920 r. w prawie 800 parafiach funkcjonowało 559 szkół. Na dzień 1 stycznia $1930 \mathrm{r}$. wykładało w nich 5519 sióstr nauczycielek, a uczęszczało łącznie 287478 uczniów ${ }^{12}$. 70\% sióstr miało pełne kwalifikacje pedagogiczne, pozostałe $30 \%$ uzupełniało je już pracując. Spośród kadry pedagogicznej zatrudnionej w polskich szkołach parafialnych 4330 sióstr zostało oddelegowanych z naszych rodzimych zakonów, natomiast 1189 sióstr z zakonów działających w innych

${ }^{10}$ The Value of Catholic Education, Golden Jubilee of st. Josaphat's Church 1884-1934, Chicago 1934, s. 47.

${ }^{11}$ „Dziennik Chicagowski” z 8.10.1942, s. 7.

12 Za: K. WACHTL, Polonia w Ameryce, Filadelfia 1944, s. 123. 
krajach (część z nich prowadziła zajęcia z przedmiotów wykładanych w języku angielskim).

Do pracy z uczniami przybyły siostry przygotowane przez: Zgromadzenie Sióstr Świętego Feliksa z Kantalicjo Trzeciego Zakonu Regularnego Świętego Franciszka Serafickiego (siostry felicjanki), Zgromadzenie Sióstr Najświętszej Rodziny z Nazaretu (nazaretanki), Polskie Siostry Szkolne św. Józefa, bernardynki, Mniszki Trzeciego Zakonu Regularnego św. Franciszka z Asyżu, Zgromadzenie Sióstr Franciszkanek Błogosławionej Kunegundy, Zgromadzenie Sióstr Franciszkanek Matki Boskiej Nieustającej Pomocy, Zgromadzenie Sióstr Zmartwychwstania Pańskiego, Zgromadzenie Córek Maryi Niepokalanej, Zgromadzenie Sióstr Kanoniczek Ducha Świętego, Zgromadzenie Sióstr Matki Bożej z Lourdes.

\section{Siostry felicjanki}

Zgromadzenie Sióstr Świętego Feliksa z Kantalicjo Trzeciego Zakonu Regularnego Świętego Franciszka Serafickiego zostało założone 21 listopada 1855 r. przez bł. Marię Angelę Truszkowską. Główne cele zgromadzenia to praca wychowawcza z dziećmi i młodzieżą oraz opieka nad chorymi i ubogimi. Felicjanki zajmują się przede wszystkim religijnym i moralnym wpływem na społeczeństwo, działalnością wychowawczo-oświatową, charytatywną, opiekuńczo-społeczną, a także działalnością misyjną. Ich zadaniem jest służenie bliźnim przez modlitwę i pracę w szkołach elementarnych i wyższych, zakładach sierot, szpitalach, przytułkach dla starców, ochronkach dla dzieci, domach dla pracujących dziewcząt i kursach katechizacyjnych ${ }^{13}$.

Pracę w polskich szkołach w USA rozpoczęły w 1874 r. w osadzie Polonia, w stanie Wisconsin, w parafii, której proboszczem był wówczas ks. Józef Dąbrowski, pomysłodawca sprowadzenia sióstr felicjanek do Ameryki. To właśnie tutaj wypracowano pierwsze zasady funkcjonowania polskich szkół parafialnych i metody pracy z dziećmi naszych emigrantów, które w latach późniejszych udoskonalano i stosowano w szeroko pojętym systemie oświaty polonijnej.

Siostry z ogromnym zapałem zaangażowały się nie tylko w edukowanie i wychowywanie uczniów, ale także podjęły intensywne działania na rzecz kształcenia nowej kadry pedagogicznej, potrzebnej do podjęcia pracy w kolejnych szkołach powstających przy polskich parafiach. W ciągu ośmiu lat od przybycia otworzyły osiem szkół parafialnych w sześciu stanach: $1877 \mathrm{r}$. - szkoła parafialna św. Jacka w La Salle (Illinois); 1878 r. - szkoła w parafii

\footnotetext{
${ }^{13}$ Siostry Felicjanki w Ameryce 1874-1944, Plymouth 1944, s. 15.
} 
św. Stanisława Kostki w Bay City (Michigan); 1879 r. - szkoła w parafii św. Wojciecha w Detroit (Michigan); 1880 r. - szkoła w parafii Najświętszej Marii Panny w Otis (Indiana); 1881 r. - szkoła w parafii św. Stanisława Biskupa i Męczennika w Buffalo (NY); 1882 r. - szkoła w parafii Matki Boskiej Nieustającej Pomocy w Chicago (Illinois).

W pierwszych latach powstawania szkół parafialnych w Stanach Zjednoczonych siostry felicjanki organizowały szkoły dwuklasowe, do których uczęszczały wyłącznie polskie dzieci w wieku od 6 do 13 lat. Uczyły w nich języka polskiego, języka angielskiego (według sześciostopniowego kursu elementarnego), religii oraz robótek ręcznych (dziewczęta). Na tej bazie budowano kolejne etapy nauczania: poziom drugi obejmował klasy od trzeciej do piątej, a trzeci - od szóstej do ósmej.

W roku 1900, niespełna 26 lat po przybyciu, siostry felicjanki prowadziły 53 polskie szkoły parafialne w najważniejszych skupiskach polonijnych Baltimore, Buffalo, Cleveland, Chicago, Detroit, Filadelfia, Toledo, Pittsburg, Saginaw $^{14}$, powstałych na terenie dziesięciu stanów: Michigan, Wisconsin, Illinois, Ohio, Pensylwania, Nowy Jork, New Jersey, Maryland, Delawere i Massachusetts. Tak duża rozpiętość terytorialna sprawiła, iż zgromadzenie działające na terenie Stanów Zjednoczonych podzielono na 6 prowincji: 1. Buffalo (stan Nowy Jork), 2. Chicago (Illinois), 3. Lodi (New Jersey), 4. Coraopolis (Pensylwania), 5. Enfield (Connecticut), 6. Rio Rancho (Nowy Meksyk).

Od 1915 r. siostry były systematycznie kierowane na studia w Katolickim Uniwersytecie w Waszyngtonie. Składały coroczne egzaminy przed stanową komisją edukacyjną, uzyskując na nich bardzo dobre wyniki. W roku 1924, z okazji obchodzonego przez zgromadzenie Złotego Jubileuszu pracy w Stanach Zjednoczonych, 56 sióstr z klasztoru detroickiego uzyskało dożywotnie dyplomy nauczycielskie wydane przez Kolegium Nauczycielskie w Detroit. Było to wielkie osiągnięcie, potwierdzające ich znakomite kwalifikacje ${ }^{15}$. Siostry felicjanki prowadziły wówczas 180 polskich parafialnych szkół podstawowych i 5 szkół średnich, w których pracowało 2228 sióstr, a kształciło się 106925 uczniów. W 1939 r. liczba szkół wzrosła do 204 szkół podstawowych i trzynastu średnich.

Według danych zaczerpniętych z The Official Catholic Directory, w 1946 r. zgromadzenie prowadziło: 214 szkół parafialnych, 24 szkoły średnie (High

${ }^{14}$ Pamiętnik Złotego Jubileuszu Zgromadzenia Sióstr Felicjanek w Ameryce 1874-1924, Detroit 1924, s. 43.

${ }^{15}$ Tamże. 
School), dwie szkoły podstawowe dla uczniów kolorowych, jedno kolegium, 3 akademie, 3 szkoły handlowe.

Największe skupiska szkół prowadzonych przez siostry felicjanki znajdowały się w Detroit (18), Buffalo (15), Chicago (14), Milwaukee (6) i Pittsburgu (5).

\section{Siostry nazaretanki}

Zgromadzenie Sióstr Najświętszej Rodziny z Nazaretu zostało założone w 1875 r. w Rzymie przez bł. Franciszkę Siedliską. Jednym z przyjętych przez nie celów była pomoc Kościołowi w pracy ewangelizacyjnej poprzez uczenie w szkołach. Rozpoczęły je w 1885 r. w polskich szkołach powołanych przy parafiach w Chicago. W dość krótkim czasie zaangażowały się w tworzenie kolejnych szkół i już na początku XX wieku 112 sióstr nazaretanek pracowało w szesnastu polskich szkołach w Chicago, Pittsburgu, Filadelfii, Brooklinie, Scranton, Camden i w Everson, kształcąc w nich ponad 9000 uczniów $^{16}$. W 1910 r. liczba szkół wzrosła do 24, a w roku 1939 do 75 szkół parafialnych i 8 średnich. W roku 1946 pracowało w nich 647 sióstr, które kształciły 22791 uczniów. Zgromadzenie prowadziło wówczas: 77 szkół parafialnych, 9 szkół średnich (High School), 3 akademie, 4 szkoły podstawowe dla uczniów kolorowych, jedną szkołę dla pielęgniarek ${ }^{17}$.

Siostry ze Zgromadzenia Najświętszej Rodziny z Nazaretu zwracały uwagę na konieczność indywidualizacji pracy z uczniami oraz na potrzebę stałego dokształcania się kadry nauczycielskiej. Swoje umiejętności i kompetencje doskonaliły w kolegium nauczycielskim Świętej Rodziny w Filadelfii ${ }^{18}$. Od 1932 r., w celu zdobycia odpowiednich kwalifikacji, wyjeżdżały na studia korzystając $\mathrm{z}$ oferty uniwersytetów europejskich, w tym Uniwersytetu Jagiellońskiego w Krakowie.

W pracy z uczniami wykorzystywały nowoczesne media, przybliżając uczniom największe osiągnięcia współczesnej nauki (np. loty w kosmos etc.). Siostry przywiązywały dużą uwagę do współpracy między szkołą i domem, dlatego często zachęcały rodziców do włączenia się w działalność grup parafialnych, takich jak: Klub Matek, Kobiece Towarzystwa Pomocowe, Fathers Guilds, Stowarzyszenia Rodzicielsko-Nauczycielskie etc. W życie szkoły angażowały także lokalne organizacje obywatelskie, prosząc je o sponsorowanie konkursów, wycieczek edukacyjnych etc., by w ten sposób zachęcić młodzież

\footnotetext{
${ }^{16}$ W. KRUSZKA, Historya polska w Ameryce..., s. 110

${ }^{17}$ The Official Catholic Directory, New York 1946.

${ }^{18}$ Historia Zgromadzenia (english), s. 302.
} 
do podjęcia nauki w polskich szkołach. Siostry w swojej pracy korzystały z pomocy profesjonalnych poradni diagnostycznych. W ramach „Great Books Program" promowały czytelnictwo. Zgromadzenie kładło duży nacisk na samodoskonalenie nauczycieli, zapewniało łatwy dostęp do zasobów bibliotecznych i widziało konieczność ciągłego wzbogacania wiedzy, zarówno ogólnej, jak i przedmiotowej. Zgodnie z ideałami zakonu nauczyciel przekazuje wiedzę wytworzoną przez umysł ludzki oraz odkrywa piękno zdeponowane w literaturze, muzyce i sztuce ${ }^{19}$.

\section{Polskie Siostry św. Józefa}

W roku 1901 ze zgromadzenia School Sisters of the Third Order of St. Francis of Assisi w Milwaukee wyłoniono Polskie Siostry Szkolne św. Józefa. Ich dom macierzysty powstał w Stevens Point (Wisconsin). Pracowały w polskich szkołach parafialnych w Chicago, Stevens Point, Detroit, Pulaski, Green Bay i Independence. W pracy edukacyjnej i wychowawczej przybliżały uczniom tradycyjne wartości kultury polskiej. Dbały, by przyszłe pokolenia emigrantów, przybyłych do Stanów Zjednoczonych, pamiętały skąd pochodzą i nie utraciły swojej tożsamości.

W 1910 r. prowadziły 29 szkół parafialnych. W ciągu dwudziestu trzech lat ich liczba wzrosła do 63 szkół parafialnych podstawowych i siedmiu szkół średnich. W roku 1946 zgromadzenie prowadziło 64 szkoły parafialne i 10 szkół średnich (High School).

\section{Siostry bernardynki}

Bernardynki, Mniszki Trzeciego Zakonu Regularnego św. Franciszka z Asyżu zostały powołane w 1454 r. w Krakowie przez św. Jana Kapistrana. Do Stanów Zjednoczonych przybyły w roku 1894 i rozpoczęły pracę w szkole parafialnej w Mount Carmel (Penna). W kolejnych latach bernardynki otworzyły kilka domów w Pensylwanii i odłączyły się od prowincji macierzystej w Krakowie, uzyskując aprobatę papieską dla utworzenia osobnego zgromadzenia. Pomimo odłączenia zachowały pierwotnego ducha religijno-narodowego. Zgromadzenie rozwijało się dynamicznie i w krótkim czasie utworzyło trzy prowincje: w Filadelfii, w Scranton i w Brazylii, objętej przez Prowincję Południowo-Amerykańską.

Siostry poza prowadzeniem szkół parafialnych, zajmowały się organizowaniem kursów religii, języka polskiego, historii i geografii polskiej dla

\footnotetext{
${ }^{19}$ Nazareth Ideals in Education, Philadelphia 1956, s. 30.
} 
dzieci naszych emigrantów, które korzystały z nauki wyłącznie w amerykańskich szkołach publicznych.

W 1910 r. zgromadzenie prowadziło 13 szkół parafialnych. Ich liczba w ciągu dwudziestu dziewięciu lat wzrosła do 38. W 1946 r. w 54 szkołach parafialnych 338 sióstr nauczycielek kształciło 11163 uczniów.

\section{Siostry św. Kunegundy}

Zgromadzenie Sióstr Franciszkanek Błogosławionej Kunegundy założone zostało w 1894 r. w Chicago przez Marię Teresę Dudzik. Pierwotnie za swój cel przyjęło opiekę nad bezdomnymi dziewczętami, starcami i kalekami. Z czasem rozszerzyło swoją działalność o pracę wychowawczą wśród chłopców (np. Boy’s Town w Nebrasce) i prowadzenie polskich szkół parafialnych. W 1946 r. 133 siostry pracowały w siedemnastu szkołach, do których uczęszczało 5115 uczniów.

Zgromadzenie Sióstr Franciszkanek Matki Boskiej Nieustającej Pomocy

W 1901 r. siostry franciszkanki rozpoczęły pracę w szkołach parafialnych w USA, ich dom generalny znajdował się w St. Louis. W 1946 r. 66 sióstr nauczycielek pracowało $\mathrm{w}$ dwudziestu jeden polskich szkołach i kształciło w nich 1761 uczniów. Według Catholic Directory w tym czasie zgromadzenie prowadziło: 32 szkoły parafialne (21 polskich), 2 kolegia, jedno seminarium. Najwięcej ich szkół było w archidiecezji St. Louis i diecezji Belleville.

\section{Siostry zmartwychwstanki}

Zgromadzenie Sióstr Zmartwychwstania Pańskiego zostało założone w $1891 \mathrm{r}$. w Rzymie przez bł. Celinę Borzęcką. W 1900 r. siostry zmartwychwstanki rozpoczęły pracę w Stanach Zjednoczonych od prowadzenia polskiej szkoły działającej przy parafii Matki Bożej Anielskiej w Chicago. Rok później powierzono im drugą szkołę w parafii św. Kazimierza w Chicago. W roku 1910 uczyły w czterech szkołach, a w 1939 r. miały 19 szkół podstawowych i 3 średnie.

Początkowo dużym problemem był brak kwalifikacji potrzebnych do wykonywania pracy nauczyciela, a także bardzo liczne klasy, które niejednokrotnie liczyły ponad stu uczniów. Młode siostry nauczycielki mogły korzystać tylko z pomocy i doświadczenia sióstr pracujących w szkołach już od dłuższego czasu, dopiero w kolejnych latach pojawiła się możliwość uczestniczenia w specjalistycznych kursach pozaszkolnych i wakacyjnych, np. oferowanych, od 1911 r., przez Catholic Sisters College w Waszyngtonie ${ }^{20}$.

\footnotetext{
${ }^{20}$ M.L. MisTECKA CR, Zmartwychwstanki..., s. 363.
} 
W 1946 r. 146 sióstr pracowało w dziewiętnastu polskich szkołach parafialnych, kształcąc 3795 uczniów. Według Catholic Directory w tym czasie siostry prowadziły: 22 szkoły parafialne (w tym 19 polskich), 2 szkoły średnie, 3 szkoły handlowe, jedną szkołę dla uczniów kolorowych ${ }^{21}$.

\section{Siostry Niepokalanego Poczęcia}

Zgromadzenie Córek Maryi Niepokalanej zostało założone w $1891 \mathrm{r}$. w Zakroczymiu przez o. Honorata Koźmińskiego i Walerię Gąsiorowską. Dom Generalny w USA znajdował się w New Britain (Connecticut). W 1946 r. 47 sióstr nauczycielek kształciło 1421 uczniów w siedmiu polskich szkołach parafialnych. W tym czasie zgromadzenie prowadziło: 8 szkół parafialnych (7 polskich), 3 domy dla pracujących dziewcząt.

Zgromadzenie działało głównie na terenie archidiecezji Newark i diecezji Hartford.

\section{Siostry Świętego Ducha}

Zgromadzenie Sióstr Kanoniczek Ducha Świętego zostało założone w 1198 r. przez bł. Gwidona z Montpellier. Siostry realizowały charyzmat miłości poprzez posługę chorym w szpitalach, domach opieki, a także przez wychowanie dzieci i młodzieży w ramach katechizacji.

W USA dom macierzysty znajdował się w miejscowości Donora, w Pensylwanii. W 1946 r. 49 sióstr kształciło 1375 uczniów w ośmiu polskich szkołach parafialnych. Zgromadzenie prowadziło w tym czasie: 11 szkół parafialnych (8 polskich), jedną szkołę średnią. Główny teren działalności to diecezja Pittsburgh.

\section{Zgromadzenie Sióstr Matki Bożej z Lourdes}

Zgromadzenie zostało założone w Stanach Zjednoczonych w 1916 r. w Sylvani (Ohio). W 1946 r. 197 sióstr nauczycielek kształciło 6725 uczniów w dwudziestu trzech polskich szkołach parafialnych. Działały głównie na terenie archidiecezji Detroit i diecezji Toledo.

W polskich szkołach parafialnych, poza siostrami oddelegowanymi do pracy z naszych rodzimych zgromadzeń, zajęcia prowadziły także siostry z zakonów działających w innych krajach. Według danych zawartych w „The Official Catholic Directory", w 1946 r. w polskich szkołach parafialnych

\footnotetext{
${ }^{21}$ The Official Catholic Directory, New York 1946.
} 
pracowało 4300 sióstr z Polski, 150 nauczycieli świeckich i 1300 sióstr z zakonów działających poza Polską 22 .

W kształcenie uczniów zaangażowały się: siostry Notre Dame, siostry franciszkanki, siostry franciszkanki konwentualne, siostry Miłosierdzia, siostry św. Franciszka, siostry bernardynki, siostry dominikanki, siostry Opatrzności, siostry Słowa Wcielonego, siostry Nieustającej Adoracji, siostry benedyktynki, siostry Świętego Krzyża, siostry Najdroższej Krwi Jezusa, franciszkanki z Lourdes, misjonarki, siostry św. Antoniego, siostry Niepokalanej Panny Marii, urszulanki, siostry pomocnicze Apostolstwa.

\section{Siostry Notre Dame}

Zgromadzenie Sióstr Szkolnych de Notre Dame powstało w 1833 r. w Neunburgu, w Bawarii. Jego celem było budowanie chrześcijańskich podstaw rodziny poprzez wychowanie dziewcząt. Zakon w 1946 r. liczył 5701 sióstr, prowadził na terenie USA i Kanady 3 college'a, 7 akademii, 124 High Schools, 418 szkół podstawowych oraz pojedyncze szkoły dla mniejszości etnicznych (indiańskiej, chińskiej i afroamerykańskiej) ${ }^{23}$.

Zgromadzenie jest pierwszym, które oddelegowało swoje siostry do pracy z uczniami w polskich szkołach parafialnych działających na terenie Stanów Zjednoczonych. Siostry Notre Dame rozpoczęły pracę w naszych szkołach w 1873 r. Pracowały w parafiach w Chicago (św. Stanisław Kostka, św. Jan Kanty), Milwaukee (św. Jadwiga, św. Jacek, św. Stanisław, św. Jozafat, św. Wincenty a Paulo), Winonie, Grand Rapids (św. Wojciech i św. Stanisław), Dubois i Berlinie (Wisconsin). W 1946 r. spośród 700 sióstr pochodzenia polskiego 277 pracowało $\mathrm{w}$ charakterze nauczycielek w dwudziestu siedmiu polskich szkołach parafialnych kształcąc 9080 uczniów.

\section{Zgromadzenie Sióstr Dominikanek Najświętszego Serca Naszej Pani}

W Stanach Zjednoczonych zgromadzenie zostało założone w $1877 \mathrm{r}$. w Grand Rapids (Michigan) i skupiało 584 siostry. Prowadziło jeden college, dwie akademie, jedną High School, jedno seminarium, 19 szkół parafialnych i 12 szkół publicznych. 25 sióstr o polskim pochodzeniu pracowało w sześciu polskich szkołach parafialnych kształcąc 912 uczniów. Głównym terenem działalności zgromadzenia była diecezja Saginaw ${ }^{24}$.

\footnotetext{
${ }^{22}$ Tamże, s. 125.

${ }^{23}$ F. BoLEK, The Polish American school system, New York City 1948, s. 56.

${ }^{24}$ Tamże, s. 62.
} 


\section{Zgromadzenie Wcielonego Słowa i Najświętszego Sakramentu}

Zgromadzenie zostało założone w San Antonio, w Teksasie. W 1946 r. liczyło 200 sióstr, w tym 10 o polskim pochodzeniu, 5 z nich uczyło 243 uczniów w dwóch polskich szkołach parafialnych w Teksasie.

\section{Zgromadzenie Sióstr Miłosierdzia}

Zgromadzenie zostało założone w 1831 r. w Irlandii. W Stanach Zjednoczonych rozpoczęło swoją działalność w roku 1929. 48 sióstr miało polskie pochodzenie - $33 \mathrm{z}$ nich pracowało w charakterze nauczycielek, kształcąc 1265 uczniów, w pięciu polskich szkołach parafialnych (1946). Działało głównie na terenie diecezji Grand Rapids i Saginaw.

\section{Zgromadzenie Sióstr Boskiej Opatrzności}

Zgromadzenie zostało założone w 1762 r. we Francji. Swoją działalność na terenie USA rozpoczęło w 1866 r. w San Antonio (Teksas). W trzech polskich szkołach parafialnych pracowało 15 sióstr mających polskie pochodzenie, kształciły w nich 538 uczniów (San Antonio, Brenham i Chapel Hill) ${ }^{25}$.

\section{Zgromadzenie Sióstr Benedyktynek}

W Stanach Zjednoczonych dom generalny zgromadzenia znajdował się w miejscowości St. Joseph, w Minnesocie. Liczył 1269 sióstr, z których 75 miało polskie pochodzenie. $14 \mathrm{z}$ nich kształciło 428 uczniów w czterech polskich szkołach parafialnych (1946). Obszar działalności zgromadzenia to diecezja St. Cloud (Minnesota).

\section{Zgromadzenie Sióstr Dominikanek III Zakonu św. Dominika}

\section{i św. Katarzyny}

Zgromadzenie posiadało dom generalny w miejscowości Saint Catharine (Kentucky). W 1946 r. liczyło 585 sióstr, w tym 8 polskiego pochodzenia: prowadziło 3 polskie szkoły parafialne, w których 12 sióstr nauczycielek kształciło 288 uczniów.

\section{Zgromadzenie Sióstr Miłosierdzia Wcielonego Słowa}

Zgromadzenie zostało założone w 1869 r. w San Antonio (Teksas). Liczyło 910 sióstr i prowadziło dwie polskie szkoły parafialne, w których kształciło 267 uczniów.

\footnotetext{
${ }^{25}$ The Official Catholic Directory, New York 1946.
} 


\section{Zgromadzenie Sióstr Miłosierdzia z Nazaretu}

W Stanach Zjednoczonych zgromadzenie zostało założone w 1812 r. w miejscowości Nazareth (Kentucky). Liczyło 1297 sióstr, w tym 5 polskiego pochodzenia. Prowadziło 3 polskie szkoły parafialne, w których 15 sióstr nauczycielek kształciło 511 uczniów (1946).

\section{Zgromadzenie Sióstr Miłosierdzia z Leavenworth (Kansas)}

Zgromadzenie zostało założone w 1851 r. i liczyło 610 sióstr, w tym 3 polskiego pochodzenia. Prowadziło dwie polskie szkoły parafialne o łącznej liczbie 105 uczniów.

\section{Zgromadzenie Sióstr Dominikanek Najświętszego Różańca}

Zgromadzenie powstało w 1877 r. w miejscowości Adrian, w stanie Michigan. Liczyło 1160 sióstr, wśród których były zakonnice o polskim pochodzeniu. Zgromadzenie prowadziło jedną polską szkołę parafialną, w której 8 nauczycielek kształciło 392 uczniów.

\section{Zgromadzenie Sióstr Służebniczek Maryi}

Zgromadzenie zostało założone w 1893 r. w miejscowości Ladysmyth, w tanie Wisconsin. Liczyło 110 sióstr, spośród których 4 miały polskie pochodzenie. Prowadziło jedną polską szkołę parafialną, do której uczęszczało 84 uczniów.

\section{Zgromadzenie Sióstr Bożej Opatrzności}

Zgromadzenie zostało założone w 1930 r. w miejscowości Normandy, w pobliżu St. Louis. Liczyło 70 sióstr, spośród których tylko jedna miała polskie pochodzenie. Prowadziło polską szkołę parafialną liczącą 215 uczniów $(1946)^{26}$.

\section{Zgromadzenie Sióstr Franciszkanek}

$\mathrm{Na}$ szczególną uwagę zasługują tutaj siostry franciszkanki. W Stanach Zjednoczonych reprezentowały kilka zgromadzeń należących do zakonu św. Franciszka. W 1900 r. w prowadzonych przez nie szkołach kształciło się 14000 uczniów, z którymi pracowało 176 sióstr nauczycielek.

Siostry franciszkanki z St. Joseph's Convent z Milwaukee pracowały w dziewięciu szkołach (Chicago, Detroit, Stevents Point, Princeton, Pulaski etc.).

\footnotetext{
${ }^{26}$ F. Bolek, The Polish American School..., s. 59.
} 
Siostry franciszkanki z St. Francis (Wisconsin) prowadziły szkoły w Pine Creek i North Creek (Wi).

Siostry ze Zgromadzenia Franciszkanek pod opieką św. Kunegundy założonego, dzięki staraniom ks. Wincentego Barzyńskiego, w 1893 r. przez Polkę matkę Annę, pracowały w polskich szkołach w Cleveland, Springvalley i Berlinie (Wisconsin). Ich dom macierzysty znajdował się w Chicago („na Jackowie").

Z pozostałych zgromadzeń polskie szkoły parafialne prowadziły: siostry benedyktynki w Minnesocie - 5 polskich szkół, siostry dominikanki w Michigan, urszulanki w Teksasie, Siostry Miłosierdzia (szarytki) w Pensylwanii i urszulanki w Teksasie.

W 1948 r., według danych zawartych w The Official Catholic Directory, polskie żeńskie zgromadzenia zakonne liczyły 8530 sióstr, a blisko 1500 sióstr polskiego pochodzenia należało wówczas do zgromadzeń wywodzących się z innych krajów. Opierając się na tych danych, można śmiało stwierdzić, iż ponad 10000 sióstr polskiego pochodzenia pracowało w amerykańskich szkołach, szpitalach i zakładach opieki.

Według opinii ks. Tomasza Reginka, autora książki Potęga katolickiej Polonii amerykańskiej, liczba ta przeczyła twierdzeniom o amerykanizacji Polonii i utracie racji bytu polskich parafii i szkół. Czytamy w niej:

Właśnie te dziesięć tysięcy sióstr polskich jest niezaprzeczalnym dowodem, że Polonia amerykańska ma prawo i obowiązek, obok prawdziwej kultury katolickiej i młodej, ale o tak indywidualnym stylu, kultury amerykańskiej, zachować wielotysięczną kulturę polską, dzięki której wnosi do Kościoła i do społeczeństwa nie tylko ilościowo, ale i jakościowo nieocenione wartości.

Z 2000 księży polskich oraz wspomnianych 10000 sióstr zakonnych przynajmniej $80 \%$ urodziło się w Stanach Zjednoczonych. Jest to dalszy dowód żywotności katolickiej Polonii amerykańskiej i nie może temu zaprzeczyć żaden jej wróg. Lecz i dla społeczeństwa ogólno-amerykańskiego zasłużyło się tych trzynaście tysięcy księży i zakonnic polskich niezmiernie, pracując nieustannie nad podniesieniem moralności publicznej, przyczyniając się do pogłębienia wartości duchowych w milionach obywateli ${ }^{27}$.

Ogromny wysiłek podjęty przez wychodźstwo polskie w Stanach Zjednoczonych na polu religijnym i oświatowym zaowocował integracją polskiej wspólnoty etnicznej i jej przetrwaniem. Gdyby nie ich świadomie podjęte działania, często trudne do udźwignięcia, prowadzące do powstawania i funk-

\footnotetext{
${ }^{27}$ T. Reginek, Potęa katolickiej Polonii amerykańskiej, Detroit 1950, s. 60 n.
} 
cjonowania polskich parafii i szkół, proces asymilacji nastąpiłby już w drugim pokoleniu, jak to miało miejsce $w$ osiedlach polskich po drugiej stronie Gór Skalistych ${ }^{28}$.

\section{FAZY ROZWOJU SZKOLNICTWA POLSKIEGO W STANACH ZJEDNOCZONYCH}

Szkoły polonijne w USA powstawały wyłącznie w systemie parafialnym (wyjątek stanowiła jedyna szkoła Związku Narodowego Polskiego w Cambridge Springs, w Pensylwanii). Ich najbardziej dynamiczny rozwój przypadł na lata 1858-1930, po czym nastąpił dwudziestoletni czas stabilizacji, a potem regres.

Emigranci polscy, po osiedleniu się w Stanach Zjednoczonych i podjęciu pracy, nie chcąc tracić kontaktu z językiem, tradycjami i kulturą polską, najpierw podejmowali decyzję o powołaniu parafii, a potem przystępowali do budowy kościoła i szkoły. Polska kultura katolicka była dla polskiego wychodźstwa w Ameryce zbyt cennym skarbem, by mogła zniknąć w atmosferze szkół publicznych. Przeciwnie, miała być pielęgnowana i przekazywana każdej kolejnej generacji przez szkoły parafialne. To był główny powód ogromnego zaangażowania Polonii amerykańskiej w sprawy oświaty i ich niezwykłej ofiarności na jej rozwój. O dynamicznym wzroście liczby polskich szkół świadczą dane statystyczne z poszczególnych lat: w 1887 r. na terenie USA było 75 polskich szkół parafialnych, w których kształciło się około 14000 uczniów; w 1900 r. - 150 szkół z liczbą uczniów około 70 000; w 1910 r. - 330 szkół; w 1914 r. - 395; w 1921 r. - 511 szkół z 260 tysiącami uczniów w szkołach parafialnych i 300 tysiącami w publicznych; w 1933 r. liczebność Polonii wzrosła do 4 milionów, a liczba szkół parafialnych do 530, kształciło się w nich ponad 300000 uczniów.

Rok 1948 przyniósł spore zmiany, liczba uczniów kształcących się w polskich szkołach parafialnych w Stanach Zjednoczonych spadła do 200000 , rozpoczął się regres. Wówczas jeszcze nie przypuszczano, że zawitał na dobre i stanie się trwałym zjawiskiem w polskiej diasporze. Zdaniem Francisa Bolka, badacza i znawcy tego procesu, złożyło się na niego kilka czynników. Jednym z ważniejszych był spadek dzietności rodzin amerykańskich, który objął swoim zasięgiem także rodziny o polskim pochodzeniu. Drugim, brak możliwości zwiększenia liczby uczniów w szkołach polonijnych o długiej tra-

\footnotetext{
${ }^{28}$ Ks. A. ICIEK, Polacy $w$ Ameryce..., s. 16 n.
} 
dycji funkcjonowania i wysokiej renomie. Kolejnym, uczęszczanie uczniów o polskim pochodzeniu do szkół publicznych i prowadzonych przez inne nacje $^{29}$.

Według Bolka pierwszy poważny cios, który spadł na polskie szkolnictwo parafialne, miał miejsce w 1929 r. i był ściśle związany z wielkim kryzysem gospodarczym. Polscy emigranci, składający się w przeważającej części z robotników, nie byli wówczas w stanie płacić w tym samym czasie obowiązkowego podatku stanowego czy municypalnego na szkolnictwo publiczne i wymaganej kwoty czesnego na szkoły parafialne. W czasie depresji gospodarczej przenosili dzieci do bezpłatnych szkół publicznych. Kolejną przyczyną spadku liczby uczniów w polskich szkołach parafialnych były częste migracje rodzin z tradycyjnych polskich dzielnic do dzielnic mieszanych narodowościowo i kulturowo. I wreszcie ostatni powód, to zmiana charakteru polskich dzielnic, spowodowana napływem innych narodowości, co skutkowało zwiększeniem liczby małżeństw mieszanych, w których dzieci nie posługiwały się już w domu językiem polskim.

Roczne tempo spadku liczby uczniów w polskich szkołach parafialnych utrzymywało się po drugiej wojnie światowej na poziomie 5\% (około 8000 uczniów mniej). Zmniejszeniu uległa także liczba uczniów uczęszczających do Polish Roman Catholic Parochial School. W 1946 r. średnio przypadało 267 uczniów na statystyczną szkołę parafialną. Były oczywiście wyjątki takie, jak: Szkoła św. Jadwigi w Chicago - 1446 uczniów, Szkoła św. Jacka w Chicago - 1120 uczniów, Szkoła św. Stanisława Biskupa w Detroit - 1227 uczniów, Szkoła św. Jacka w Detroit - 1003 uczniów. Wyjątki te dotyczyły dużych miast z wielotysięczną polską diasporą (Buffalo, Chicago, Cleveland, Detroit, Filadelfia, Milwaukee etc.).

Zmniejszeniu ulegała także liczba sióstr nauczycielek, w 1930 r. było ich 5395, a w 1946 - 4684. W związku z tym siostry dotychczas pracujące w szkołach były przenoszone do pracy w szpitalach i w sektorze pomocy socjalnej.

Pomimo ciągłego spadku liczby uczniów w polskich szkołach parafialnych, liczba młodzieży polskiego pochodzenia przebywających na stałe w Stanach Zjednoczonych wyglądała nadal imponująco i odzwierciedlała siłę Polonii amerykańskiej. W 1946 r. w polskich szkołach parafialnych kształciło się 180000 uczniów, w szkołach katolickich prowadzonych przez inne narodowości - 431000 uczniów, a 841000 uczniów w szkołach publicznych, łącznie 1452000 uczniów polskiego pochodzenia.

\footnotetext{
${ }^{29}$ F. BOLEK, The Polish American school..., s. 5.
} 
W historii polonijnego szkolnictwa parafialnego w Stanach Zjednoczonych możemy wyróżnić cztery okresy rozwoju i dominacji przyjętych idei wychowawczych:

1. Od początku powstania polskich szkół w Ameryce do końca lat dwudziestych XX wieku (do czasu wielkiego kryzysu gospodarczego 1929-1933) dominowała idea pełnej identyfikacji z narodem polskim i jego kulturą.

2. Lata 1929-1945 - okres przeobrażeń i rozmycia identyfikacji z narodem polskim, był czasem wielkich dyskusji nad samookreśleniem miejsca Polonii w społeczeństwie amerykańskim.

3. Lata 1945-1970 - czas wzmożonej asymilacji i spadku zainteresowania szkolnictwem parafialnym.

4. Lata 1970-1990 - okres renesansu etnicznej świadomości inspirowany wyborem kardynała Karola Wojtyły na papieża Kościoła Powszechnego oraz powstaniem w Polsce ruchu „Solidarność” i jego przywództwem w Europie Środkowo-Wschodniej w walce o wolność i prawa obywatelskie.

Tabela 1. Dynamika rozwoju polskich szkół parafialnych w USA w szczytowym okresie

\begin{tabular}{|c|c|c|c|}
\hline Rok & Liczebność Polonii & Liczba parafii & Liczba szkół \\
\hline 1870 & 40000 & 17 & 6 \\
\hline 1880 & 260000 & 75 & 35 \\
\hline 1890 & 800000 & 170 & 100 \\
\hline 1900 & 1500000 & 390 & 300 \\
\hline 1910 & 2800000 & 512 & 350 \\
\hline 1915 & 3263000 & 685 & 483 \\
\hline 1920 & 3400000 & 760 & 530 \\
\hline 1930 & 4000000 & 830 & 560 \\
\hline
\end{tabular}

Wzrost liczby polskich szkół parafialnych w Stanach Zjednoczonych był wprost proporcjonalny do rozwoju sieci polskich parafii. W ciągu trzydziestu lat (od 1890 do 1920 r.) ich liczba wzrosła pięciokrotnie, ze stu do pięciuset trzydziestu, a wraz z nią poziom kształcenia.

Konsul Generalny RP w Buffalo w raporcie z 1922 r. napisał: „Na zasadzie szkół publicznych zakładane są szkoły parafialne przy kościołach rzymsko-katolickich i niezależnych, w których nauka oparta jest na identycznych programach, jak w szkołach publicznych [...] poziom i system nauczania w szkołach parafialnych stale się poprawia [...]. Nie mylimy się twierdząc - że dotychczas najskuteczniejszym środkiem przeciw szybkiemu 
zamerykanizowaniu się pokoleń, tu urodzonych była i jest szkoła parafialna, na co też zwróciły już uwagę - niektóre sfery szowinistyczne amerykańskie - co wyraża się stawianiem wniosków o likwidację szkół parafialnych"30.

Szkoły parafialne przez cały czas istnienia uwzględniały w programie nauczania naukę języka, historii i kultury Polski. Chciały wykształcić i wychować „Polaka amerykańskiego”, a później „Amerykanina polskiego pochodzenia", wiernego członka Kościoła i polonijnej wspólnoty (parafii), sumiennego obywatela i dobrego patriotę Polski oraz Stanów Zjednoczonych ${ }^{31}$.

Niestety, rozpoczęte $\mathrm{w}$ okresie międzywojennym procesy asymilacyjne, które nasiliły się po drugiej wojnie światowej, sprawiły, iż zorganizowane z tak wielkim trudem szkolnictwo polskie w USA stało się integralną częścią systemu szkolnictwa amerykańskiego. Jedynie część szkół, mających oparcie w rodzimej parafii, zachowało tradycję nauczania języka i kultury polskiej.

\section{BIBLIOGRAFIA}

Bolek F., The Polish American school system, New York City: Columbia Press Corporation 1948.

Encyklopedia polskiej emigracji i Polonii, red. K. Dopierała, t. IV, Torun: Oficyna Wydawnicza Kucharski 2005.

ICIEK A., Polacy w Ameryce, Poznań 1921.

Kruszka W., Historya polska w Ameryce. Początek, wzrost i rozwój dziejowy osad polskich w Północnej Ameryce (W Stanach Zjednoczonych i Kanadzie), t. II, Milwaukee: Drukiem Spółki Wydawniczej Kuryera 1905.

MisteCKA M.L., Zmartwychwstanki. Charyzmat i dzieje 1891-199, t. II: Dziedzictwo (Biblioteka Polonii, t. 22), Lublin: Instytut Badań nad Polonią i Duszpasterstwem Polonijnym KUL, Oddział Lubelskiego Stowarzyszenia „Wspólnota Polska” 1999.

Reginek T., Potęga katolickiej Polonii amerykańskiej, Detroit: Conventual Press 1950.

TARAs P., Polonia w Detroit. Problem kulturowej tożsamości i społecznego awansu. Socjologiczne studium społeczności etnicznej w USA, Warszawa: Pallottinum 1989.

Ziolkowski J., The Felician Sisters of Livonia, Michigan: First Province in America, Detroit: Harlo Press 1984.

\footnotetext{
${ }^{30}$ Archiwum Akt Nowych w Warszawie, 966, Memoriał w sprawie szkolnictwa parafialnego w Stanach Zjednoczonych. Konsulat R.P. w Buffalo. Odpowiedź na kwestionariusz MSZ z 07.07.1922.

${ }^{31}$ P. TARAS, Polonia w Detroit. Problem kulturowej tożsamości i spolecznego awansu. Socjologiczne studium społeczności etnicznej w USA, Warszawa 1989, s. 209.
} 


\section{SZKOLNICTWO POLSKIE W STANACH ZJEDNOCZONYCH}

\section{Streszczenie}

Szkolnictwo polskie za granicą było i jest nadal filarem utrzymującym polską kulturę i tożsamość narodową wspólnoty polskiej na wychodźstwie. Wśród wielu cennych inicjatyw oświatowych polskich emigrantów datujących się od roku 1842, szkolnictwo polskie w Stanach Zjednoczonych zajmuje czołowe miejsce pod względem liczby utworzonych szkół, uczniów i nauczycieli oraz znaczenia w procesie integracji środowiska polonijnego. Artykuł przedstawia genezę szkolnictwa polskiego w USA, jego fazy rozwoju oraz ukazuje najważniejsze problemy, takie jak zorganizowanie profesjonalnej kadry nauczycielskiej, utworzenie systemu finansowania szkół i stawianie czoła procesom asymilacyjnym. Artykuł zawiera istotne dane statystyczne i charakteryzuje żeńskie zgromadzenia zakonne kształcące młodzież w szkołach parafialnych pierwszego i drugiego stopnia.

Słowa kluczowe: szkolnictwo polskie w USA; Polonia amerykańska; szkolnictwo parafialne w Stanach Zjednoczonych

\section{POLISH EDUCATION IN THE UNITED STATES}

Summary

Polish education abroad has always been a pillar supporting Polish culture and national identity for the Polish community in exile. Among the many valuable educational initiatives of Polish emigrants going back to 1842, the Polish education system in the United States occupies a leading position in terms of the number of schools established, the number of students and teachers, and its importance in the process of integrating the Polish diaspora. The article presents the genesis of Polish education in the United States, its developmental stages, and shows the most important problems, such as organizing professional teaching staff, creating a school financing system, and facing assimilation processes. The article contains important statistical data and characterizes female religious congregations educating youth parish schools of the in first and second levels.

Keywords: Polish education in the USA; Polish Americans; parish education in the United States 